\title{
A Versatile Flail-Type Forage Plot Harvester
}

\author{
J. STUBBENDIECK AND CHARLES R. FENSTER
}

\section{Abstract}

A flail-type plot harvester was developed using commercially manufactured components and a specifically designed and constructed forage collection box. This forage plot harvester has been used successfully on experimental rangeland and seeded forage plots. The equipment is more versatile and less expensive than commercially manufactured plot harvesters.

Forage research is dependent on the successful quantification of vegetative response. Several different characteristics have been evaluated to measure vegetative response. However, the most universally accepted criterion is yield. Weight of herbage produced per unit area (yield) is one of the most important characteristics of range plants, and it is probably the best single measure of growth (Hanson 1950). Yield is also one of the most labor intensive and time consuming vegetative characteristics to quantify, particularly when the historical technique of hand clipping is employed. The recognized importance of yield data to forage research has emphasized the need for more efficient, economical methods of experimental plot harvesting.

Brown (1954) and Mannetje (1978) have discussed the many techniques and types of plot harvesting equipment which include hand and electric clippers, sickle and rotary mowers, and flail choppers. Each harvesting technique has its advantages and disadvantages. Hand and electric clippers are relatively inexpensive, but plot size may be limited due to labor requirements. Numerous researchers have used rotary mowers, but many found that tall plant material was difficult to harvest (Howell 1956; Fortmann 1956; McGinnies 1959). Several self propelled flail-type forage harvesters have been developed and tested (Kemp and Kalbfleisch 1957; Hubbard and Willis 1962; Thompson and Heinrichs 1963; Buker 1967; Swallow 1967; Allen et al. 1968; Collins et al. 1969). Flail-type plot harvesters were more labor efficient, but they were expensive and could be used for only one purpose, because the mower was permanently attached to the tractor, allowing no versatility in tractor use. This paper describes a rather simple, efficient, relatively economical, and versatile forage plot harvester that has been used successfully on experimental rangeland and seeded forage plots.

\section{Harvester Design and Operation}

The harvester is a combination of three main components: (1) a garden tractor, (2) a commercially manufactured front-mounted flail mower, and (3) a specifically designed and custom constructed forage collection box. Garden tractors in a 12 to 16 h.p. range with both standard and hydrostatic transmissions were evaluated. The larger tractor (John Deere 316) ${ }^{1}$ with the hydrostatic transmission has been the most satisfactory combination. The hydrostatic transmission eliminates the problem of clutch slippage at reduced speed. The Haban $512^{1}$ flail mower has a cutting width of $91 \mathrm{~cm}$. It is belt driven by an electric p.t.o. at 1,800 to 2,200 rpm. Normal revolu-

Authors are associate professor of Agronomy (Range Management), University of Nebraska, Lincoln 68583; and professor of agronomy, University of Nebraska Panhandle Station, Scottsbluff 69361.

This paper is published as Paper Number 5807, Journal Series, Nebraska Agricultural Experiment Station.

Manuscript received June 18, 1979.

\footnotetext{
Mention of a proprietory name does not constitute endorsement by the University of Nebraska.
}

tion direction of the rotor was reversed (factory option). This causes the harvested forage to be moved forward and lifted toward the top of the mower. The mower must be equipped with a removable top cover (factory option). The top cover is removed and a piece of sheet metal $(9 \times 96 \mathrm{~cm})$ and a $90^{\circ}$ bend is attached to the lower lip of the opening. This sheet metal deflector (Fig. 1A) forces the harvested forage into the collection box.

The collection box is $132 \mathrm{~cm}$ wide and is constructed of angle iron and sheet metal. Its lid (Fig. 1B) latches in a closed position and hinges back over the hood of the tractor in the open position. The ends of the collection box, as well as two areas in the lid, have inserts of hardware cloth (Fig. 1C), which allows air to escape causing an even distribution of forage in the collection box.

Cutting height is set by raising or lowering the gauge wheel (Fig. 1D) by adding or removing spacers (Fig. 1E) on the wheel bracket shaft. The flail roller (Fig. 1F) levels the mower. The level may be altered by changing the flail roller adjustment (Fig. 1G).

This harvester has been used on irrigated and dryland grasses, legumes, and grass-legume mixtures, as well as on rangeland. Cutting speed was approximately $1 \mathrm{~m} / \mathrm{sec}$. Cutting heights have varied from 2.5 to $15.0 \mathrm{~cm}$. At the lower cutting heights, a trace of soil has been detected in the samples. At the higher cutting heights, a small portion of the plant material is deposited on the soil surface.

The collection box will hold up to $15 \mathrm{~kg}$ of harvested forage. This capacity makes it possible to harvest forage plots of sufficient size, even those that are irrigated. Forage is removed from the collection box and weighed separately. Representative subsamples are relatively simple to obtain because harvested plant material is coarsely ground and mixed. Subsamples are dried to determine moisture content and may be ground and analyzed for various quality parameters.

\section{Advantages}

This harvester has several advantages over commercially manu-

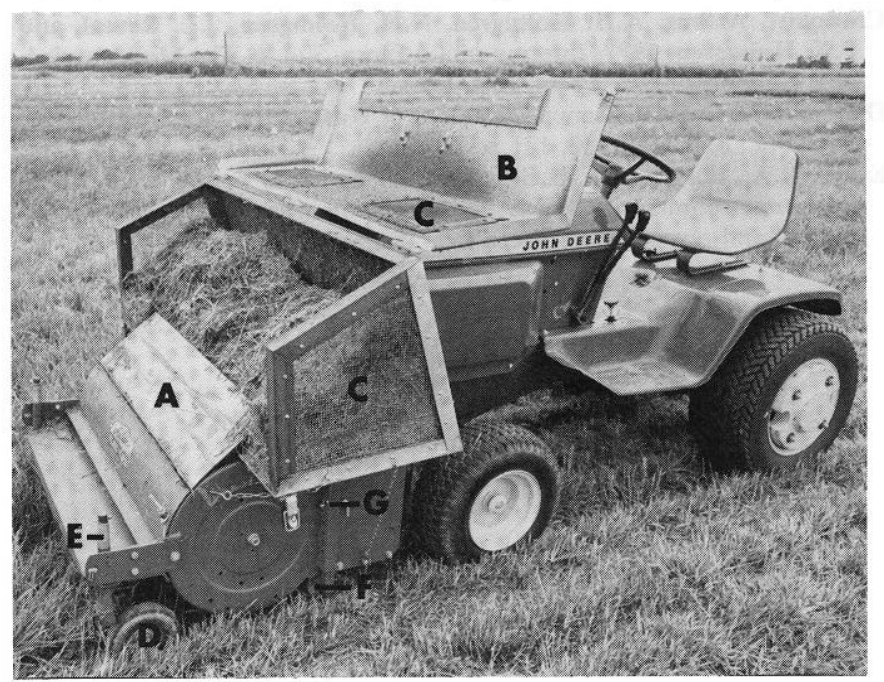

Fig. 1. Versatile plot harvester showing (A) forage deflector, $(B)$ hinged collection box lid, (C) hardware cloth inserts, (D) gauge wheel, (E) gauge wheel spacers, $(F)$ flail roller, and $(G)$ flail roller adjustment. 
factured flail-type harvesters. One advantage is lower cost. The cost of our harvester in 1978 was approximately $\$ 3,100$ : (1) 16 h.p. hydrostatic tractor, $\$ 2,350$; (2) flail mower, $\$ 600$; and (3) custom constructed collection box, $\$ 150$. This compared to an approximate cost of $\$ 7,000$ for a commercial flail-type harvester.

The harvester is easily transported. It can be hauled in a $1 / 2 \mathrm{~T}$ pickup. We constructed a tilt-bed trailer, but a snowmobile trailer would work equally well. Another advantage is versatility. The collection box can be easily removed and the mower top cover replaced in a few minutes. The machine may then be used for cutting plot alleys and other routine mowing. The entire flail mower assembly may also be removed from the garden tractor in approximately 15 minutes. The garden tractor may then be used as the power source for numerous small implements.

\section{Literature Cited}

Allen, R.J., T.W. Casselmann, and F.H. Thomas. 1968. An improved forage harvester for experimental plots. Agron. J. 60: 584-585.

Brown, Dorothy. 1954. Methods of surveying and measuring vegetation. Bull. 42. Commonwealth Agr. Bur. Hurley, Berkshire, England. 223 p.
Buker, R.J. 1967. Forage plot harvester. Agron. J. 59:203-204.

Collins, K.L., C.L. Rhykerd, and C.H. Noller. 1969. A self-propelled experimental plot forage harvester. Agron. J. 61:338-339.

Fortmann, H.R. 1956. Harvester for experimental forage plots. Agron. J. 48:241-242.

Hanson, Herbert C. 1950. Ecology of the grassland II. Bot. Rev. 16:283360.

Howell, H.B. 1956. A new experimental plot harvester. Agron. J. 48:240241.

Hubbard, W.A., and T.G. Willis. 1962. Note on a self-propelled flail-type forage plot harvester. Canadian J. Plant Sci. 42:739-741.

Kemp, J.G., and William Kalbfleisch. 1957. A crop harvester for forage plots. Canadian J. Plant Sci. 37:418-422.

Mannetje, L. 't. 1978. Measurement of grassland vegetation and animal production. Bull. 52. Commonwealth Agri. Bur. Hurley, Berkshire, England. $260 \mathrm{p}$.

McGinnies, W.J. 1959. A rotary lawn mower for sampling range herbage. J. Range Manage. 12:203-204.

Swallow, Clarence. 1967. Self-propelled plot forage harvester. Agron. J. 59:609-610.

Thompson, J.L., and D.H. Heinrichs. 1963. Note on the Swift Current Forage Plot Harvester II. Canadian J. Plant Sci. 43:602-604. 